\title{
Does Introduction of Stock Options Impact Stock Volatility? Empirical Evidence from Underlying Stocks in Indian Market
}

\author{
Himanshu Joshi \\ FORE School of Management, New Delhi, India \\ Email: himanshu@fsm.ac.in
}

How to cite this paper: Joshi, H. (2018) Does Introduction of Stock Options Impact Stock Volatility? Empirical Evidence from Underlying Stocks in Indian Market. Theoretical Economics Letters, 8, 1803-1815. https://doi.org/10.4236/tel.2018.810118

Received: May 1, 2018

Accepted: June 18, 2018

Published: June 21, 2018

Copyright $\odot 2018$ by author and Scientific Research Publishing Inc. This work is licensed under the Creative Commons Attribution International License (CC BY 4.0).

http://creativecommons.org/licenses/by/4.0/

\section{(c) (i) Open Access}

\begin{abstract}
Present study investigates the impact of single stock option trading on the volatility of the underlying stocks in Indian market using data of companies listed on National Stock Exchange (NSE) of India. The daily stock price data for a period of 1 year prior and post option introduction is extracted for 166 companies which offer options trading on the platform of NSE. Pre and post volatility of the underlying stocks is measured using standard deviation and GARCH $(1,1)$ model. Then the sample has been split into three groups based on the market capitalization of the stocks, i.e., large cap, mid cap, and small cap. Pre and post option listing volatility was tested for three groups separately. The highest average volatility is recorded for large cap stocks, followed by mid cap, and lowest for small cap stocks using GARCH $(1,1)$ model. This contrasts with the results of daily variance, as variance is highest for the small cap, followed by large cap and lowest for mid cap firms. Results show that for the large cap firms, volatility increases after the option listing, using both the measure of measures of volatility; and statistically insignificant decline has been recorded in the daily variance and average long-run volatility measure $\left(\mathrm{V}_{\mathrm{L}}\right)$ using $\mathrm{GARCH}(1,1)$ model for mid cap, and small cap firms.
\end{abstract}

\section{Keywords}

Single Stock Options, Volatility, GARCH $(1,1)$

\section{Introduction}

The primary objective of the introduction of financial derivatives is to provide investors with an opportunity to hedge risk. Derivatives also increase liquidity of the underlying asset market, thereby making it more information efficient. However, financial derivatives are often criticized for destabilizing the underly- 
ing spot markets. In fact, asset securitization and misuse of financial derivatives, specifically CDS (Credit Default Swaps) played a critical role in global financial crisis of 2008. Academic literature is divided on the issue of whether the financial derivative stabilizes or destabilizes the underlying asset market. When commodity futures were first introduced on the Chicago Board of Trade in 1865, market regulators were concerned about the impact of futures on the underlying commodity spot market, as future trading attracts speculators who then destabilize spot prices. Unlike futures, which is contract to buy (or sell) the underlying asset at a certain price during the life or on expiration of the contract and under which both the parties are under obligation to honour the contract; an option gives the holder of that option right to buy (or sell) the underlying asset in predetermined quantities for a certain price at any time during its life or on its expiry date. Pricing or value of an option depends greatly on the volatility of the underlying asset, in addition to the other factors like time to expiration, risk free rate of interest, exercise price, and spot rate. In fact, options on highly volatile underlying assets, attract higher price in option trading. Thus, it is imperative to ask whether the introduction of option contract make the underlying asset market more volatile. In competitive and frictionless market, option payoff can be replicated with that on a portfolio of the underlying stock and a risk free bond, and in such a complete market, introduction of option should have no impact on the underlying stock [1]. However, actual markets are incomplete and far from perfection, and in such markets options listing and subsequent trading may affect the underlying asset market behavior, including their prices, liquidity, and volatility. Present paper intends to study impact of option listing on the volatility of underlying stocks, using a sample of option listing on individual stocks from the National Stock Exchange (NSE) of India. NSE launched trading in options on individual securities in July 2001. These option contracts are European style and cash settled. Stock options are available on 175 securities, stipulated by Securities and Exchange Board of India (SEBI). SEBI has prescribed following criteria for stock option listing: 1) the stocks are selected from the top 500 stocks in terms of average daily market capitalization and average daily traded value in the previous six months on a rolling basis; 2) the stock's median quarter-sigma order size over the last six months should not be less than Rs. 10 lakh. Quarter sigma order size is a value-at-risk ( $\mathrm{VaR})$ measure calculated using the J.R. Verma committee guidelines, which consider stock's trading volume (liquidity) as the criteria for stock selection. Since, stock selection criteria at national stock exchange has already taken stock's liquidity into consideration, volatility aspect of the stock option listing has been investigated in the current study. Option contracts have maximum of 3 months trading cycle - the near month (one), the next month (two), and next month (three). On expiry of the near month contract, new contacts are introduced at new strike prices for both call and put options on the trading day following the expiry of the near month contract. Base price of the option contracts, on introduction of new contracts, would be theo- 
retical value of the option contract arrived at based on the Black-Scholes model of calculation of option value.

Unlike United States, index options in India were introduced earlier than the equity options on individual stocks. Index options based on Nifty-50 were introduced by NSE on June 4, 2001, while options on individual securities were introduced one month later in July 2, 2001. Mayhew and Mihov [2] predicted that with index products already in place in emerging markets, exchanges may find it difficult to generate much interest in the individual stock options. In United States, index derivatives were launched more than a decade later than equity options and that the use of individual stock options to hedge against market risk for lack of index derivatives contributed to the success of equity options in the United States. Alternatively, if index options complete the market for the component stocks, in the spirit of the market completion hypothesis, as postulated by Detemple and Jorion [3] [4], the introduction of equity option should have no impact on the underlying asset market. Empirical evidence from another developed market Japan, where individual stock options were introduced later than the index options, shows that listing of stock options still cause significant increases in volatility for the underlying stocks [5].

Present study is a worthwhile effort to evaluate the impact of stock options listing on the volatility of underlying stocks in Indian market, which is similar to the Japanese market in terms of offering of stock options after the index options, but lag period is just short of one month. Division of sample into three groups based on the underlying stock's market capitalization, namely large cap, mid-cap, and small-cap is another contribution of the paper. By dividing the sample, study examines whether larger firms in sample are impacted differently by the initial option listing than the smaller firms. Furthermore, with additional data from an emerging market country, paper provides variability of empirical evidences on option listing and stock volatility. The rest of the paper is organized as follows: Section 2 reviews the relevant literature, Section 3 describes the data and methodology, Section 4 presents findings and analysis, and Section 5 provides the conclusion.

\section{Literature Review}

Several studies on the effect of listing and trading of index futures and index options on the volatility and efficiency of underlying spot market have been conducted. The empirical evidence is mixed and most of them suggest that the introduction of derivatives do not destabilize the underlying spot market. Evidence also suggests that introduction of derivatives contracts improves liquidity and reduces informational asymmetries in the market. Information asymmetries have direct bearing on the volatility of underlying asset. Unlike futures and forward contracts, pricing of options rely heavily on volatility of the underlying asset. Ross [6] was the first to argue that options trading can convey important information in a market with information asymmetry by expanding the contin- 
gencies that are covered by traded securities. Black [7] notes that informed traders can use options markets as an alternative venue for trading because option contracts provide higher leverage. Detemple [3] [4] and Detemple and Selden [8] showed that, when the market is incomplete, newly introduced options in equilibrium could either depress or enhance the price for the underlying stocks. Easley, O'Hara and Srinivas [9] argued that options can be more attractive for informed traders because the availability of multiple contracts confronts uninformed traders with substantial challenges. Investors use option contracts for hedging purposes, which increase the trading demand in the underlying asset market [6] and Hakansson (1982). In the presence of information asymmetry under the incomplete market conditions, increased hedging transactions can reduce the probability of informed trading by the investors. Cao [10] showed that option trading motivates uninformed investors to gather more private information about the underlying stock/firm, which in turn lead to improved price informativeness.

Moreover, options are a mechanism for trading on information about future equity volatility, which allows investors with stock price volatility to benefit from options [11]. On the whole, introduction of derivatives contracts (both futures and options) seems to improve liquidity and informational efficiency of the underlying spot market. On the volatility impact of option trading, Grossman [12] argues that option prices convey new information to the underlying market (positive information externally), resulting in lower price volatilities there. However, if the information transmitted contaminates the information content of the stock price (negative information externality), Stein [13] showed that the underlying market would be destabilized. Bhamra and Uppal [14] demonstrated when the market is incomplete, option listing increases the underlying stock market volatility. However, empirical evidence does not provide conclusive answer for the underlying asset's volatility. Unlike in United States, stock options were introduced later than the introduction of index options in many of the other developed and emerging markets. Long, Schinski, and Officer [15] divided the sample of option traded stocks by their market value to determine whether larger firms are impacted differently by option listing than smaller firms. They did not find any evidence of changes in price volatility following option listing. Liu [5] argued that if index options complete the market for the component stocks, in the spirit of the market completion hypothesis, the introduction of equity option should have no impact on the underlying asset market. However, empirical evidence from his study on another developed market Japan, where individual stock options were introduced later than the index options, shows that listing of stock options still cause significant increases in volatility for the underlying stocks. Chen and Chang [16] provide evidence of stock option listing on underlying securities' abnormal return, volatility, and trading volume from Taiwan. Results of their study show that post listing of the stock options, positive abnormal returns exist, the degree of volatility decreases, and trading volume 
increases. Dong, Fan, and Zhang [17] provide cross country and regions evidence from Asia, including mainland China, Japan, Hong Kong, Malaysia, Korea, Taiwan, and Singapore on introduction of stock index futures on the spot market volatility, and report short term increase in volatility.

In the context of Indian market, limited studies are available on the impact of derivative market trading and its impact on the underlying spot market. Vipul [18] analyzed the effect of introducing derivative contracts in Indian market using six underlying stocks, and an index. His results provide evidence of reduction in the volatility of the underlying stocks after the derivative listing. Chaturvedula [19] investigates the existence of positive abnormal return in context of derivative (both futures and options) listing on the underlying assets in India, and reports significant positive abnormal returns around the derivative listing.

To summarize the literature review, options trading completes the market and reduce information asymmetry in following three ways-by providing leverage to financially constrained informed investors, by relaxing short sale constraints on stocks, and by motivating informed investors to gather private information about the underlying stocks. Options trading also provides a mechanism for trading on information about future equity volatility, which allows investors with stock price volatility to benefit from options trading. Reduced information asymmetry and the mechanism for trading on future stock volatility makes the underlying assets prices more efficient. However, on the volatility front, empirical evidences are diverse. On one hand, studies by Bhamra and Uppal [14] using option listing data from US, and Liu [5] using similar data on Japan, reports significant increase in the volatility of underlying stocks on the listing of option contracts. On the other hand, study by Chan and Chang [16] using option listing data from Taiwan reports decrease in volatility for the underlying asset market. Also, Dong, Fan, and Zhang [17] taking cross country and regions data from Asia, including mainland China, Japan, Hong Kong, Malaysia, Korea, Taiwan, and Singapore report short term increase in volatility. In the context of Indian market, adequate evidences are not available on option listing and stock volatility, as most studies focus on futures and option listing on the indices, and not the individual stocks. Moreover sample size of these studies is quite small for generalization. Present study addresses this concern and investigates the impact of single stock option trading on the volatility of the underlying stocks in one of the fastest growing emerging markets using data of companies listed on National Stock Exchange (NSE) of India. Emerging markets like India are likely to experience excessive informational asymmetry in comparison to the developed market. Moreover, in India unlike the US market, stock options were introduced later than the introduction of index options, which provides an interesting setting to investigate the impact of option listing on the underlying stock volatility in the absence of market completion hypothesis.

Therefore, introduction of option trading in Indian market is likely to have significant impact on the volatility of the underlying asset. Selection of variance 
and GARCH $(1,1)$ model as measures of volatility is supported by the previous work done by Bollerslev [20], and Andersen \& Bollerslev [21]. Their study shows that traditional tests of various volatility models which rely on ex-post squared (absolute) returns are a very noisy (although unbiased) estimate of volatilities. These studies recommended the use of high frequency data in volatility estimation using GARCH models.

\section{Data and Methodology}

The data for option listing and underlying stock prices is retrieved from the national stock exchange equities archives. The daily stock price data for a period of 1 year prior and post option introduction is extracted for all 175 companies' stocks on which options trading is active on the national stock exchange. However, after removing some companies having incomplete data on account of cancellation option trading in absence of insufficient trading volume, only 166 companies were available for the study. Pre and post volatility of the underlying stocks is measured using variance $\left(S^{2}\right)$ and long-run variance $\left(\mathrm{V}_{\mathrm{L}}\right)$ using generalized auto-regressive conditional heteroscedasticity $\operatorname{GARCH}(1,1)$ model. Variance is a measure of total risk of the stock and is measured as:

$$
S^{2}=\sum \frac{(X-X-)^{2}}{N-1}
$$

GARCH $(1,1)$ model proposed by Bollerslev [20] is a statistical time series model that enables to model volatility as time varying and predictable. GARCH techniques explicitly model the volatility process over time and enable to explore the link between information/news arrival in the market and its impact on market volatility. In GARCH $(1,1)$ model the period $t$ conditional volatility is a function of period n-1 conditional volatility and the return from $(n-1)$ to n-squared:

$$
\sigma_{n}^{2}=\omega+\alpha \mu_{n-1}^{2}+\beta \sigma_{n-1}^{2}
$$

$\alpha=$ weighting on the previous period's return; $\beta=$ weighting on the previous volatility estimate; $\omega=$ weighted long-run variance $=\Upsilon \mathrm{V}_{\mathrm{L}}$;

$$
\mathrm{V}_{\mathrm{L}}=\text { Long }- \text { run average variance }=\frac{\omega}{(1-\alpha-\beta)}
$$

The $(1,1)$ in GARCH $(1,1)$ model indicates that $\sigma_{n}^{2}$ is based on the most recent observation of $\mu^{2}$, and the most recent estimate of the variance rate, $\sigma_{n-1}^{2}$.

Study has preferred a sample of individual stocks with options trading to the sample of index options, for former is expected to have a more direct relation between option trading and asset volatility than the later. Variance and long run variance using GARCH $(1,1)$ model for all the 166 stocks are compared for sample period of one year before the introduction of stock options with the sample period of one year after the introduction of stock options. T-test were conducted to test the significance of difference between volatility measures for pre and post option listing periods. Then the sample was split into three groups based on the 
market capitalization of the stocks, i.e., large cap, mid cap, and small cap. On national stock exchange of India, large cap stocks have market capitalization ranging between INR. 200 billion (US \$3 billion) to INR. 3500 billion (US \$55 billion), mid cap stocks have market capitalization ranging between INR. 50 billion (US $\$ 770$ million) to INR. 200 billion (US \$3 billion), while small cap stocks have market capitalization lower than INR. 50 billion (US $\$ 770$ million). Out of the total of 166 firms, there are 88 large cap firms, 55 mid cap firms, and 23 small cap firms. Pre and post option listing volatility was tested for three groups separately.

\section{Findings and Analysis}

To test whether the variances of return for all the 166 firms have changed subsequent to the stock option listing, a "not equal to" alternative hypothesis is formulated.

$$
\begin{aligned}
& H_{0}: \sigma_{\text {Before }}^{2}=\sigma_{\text {After }}^{2} \\
& H_{a}: \sigma_{\text {Before }}^{2} \neq \sigma_{\text {After }}^{2}
\end{aligned}
$$

A test concerning differences between the variance of the two populations is based on the ratio of sample variance, $\mathrm{F}=\sigma_{\text {Before }}^{2} / \sigma_{\text {After }}^{2}$, with $\mathrm{df} 1=n_{1}-1$, numerator degree of freedom and df $2=n_{2}-1$ denominator degree of freedom, F-Critical at 5\% significance level is computed to be 1.232 . Therefore, if null hypothesis is not rejected, then it shows that there is no significant difference between the pre and post option listing variance of the underlying stock. Contrary to this, if null hypothesis is rejected (alternative hypothesis is accepted), it confirms that there is statistically significant difference between the pre and post option listing variance of the underlying stock.

Table 1 presents the result of hypotheses test on individual firm's variance for the sample of large cap, mid cap, and small cap firms.

Out of 166 firms, for only 62 firms, the null hypothesis is not rejected at 5 percent significance level, while null hypothesis is rejected for remaining 104 firms. Therefore, for 104 firms, there is a significant change in total risk measure i.e., variance, subsequent to the stock option listing, and for remaining 62 firms, variance has not changed significantly. Subsequent of the stock option listing,

Table 1. Results of hypotheses test for change in variance on sample of large cap, mid cap, and small cap firms.

\begin{tabular}{ccccc}
\hline $\begin{array}{c}\text { Sub Sample of } \\
\text { Firms }\end{array}$ & $\begin{array}{c}\text { Null Hypothesis } \\
\text { Accepted (A) } \\
\sigma_{\text {Before }}^{2} / \sigma_{\text {After }}^{2}<\mathrm{F} \\
\text { Critical }\end{array}$ & $\begin{array}{c}\text { Null Hypothesis } \\
\text { Rejected }(\mathrm{B}) \\
\sigma_{\text {Before }}^{2} / \sigma_{\text {After }}^{2}>\mathrm{F} \\
\text { Critical }\end{array}$ & $\begin{array}{c}\text { Total } \\
(\mathrm{C})\end{array}$ & $\begin{array}{c}\text { Significant Change in } \\
\text { Variance (in percent) } \\
(\mathrm{B}) /(\mathrm{C})\end{array}$ \\
\hline Large Cap & 27 & 61 & 88 & $69.32 \%$ \\
Mid Cap & 20 & 35 & 55 & $63.64 \%$ \\
Small Cap & 15 & 8 & 23 & $34.78 \%$ \\
Total & 62 & 104 & 166 & $62.65 \%$ \\
\hline
\end{tabular}


the variance has change significantly for 69.32 percent of the large cap firms, 63.64 percent for the mid cap firms, and only 34.78 percent for the small cap firms. Therefore, it can be summarized from Table 1 that for large cap and mid cap firms, there is a substantial impact of option listing on the firms' total risk measure, variance. However, only a small percentage of the small cap firms have shown significant change in variance. The rationale for the change in variance for the large cap and small firms after stock option listing can be the augmented informed trading in the underlying stocks.

To know the overall effect of option listing on the firm variance, a two sample t-test is conducted using variance data of 88 large cap, 55 mid cap, and 23 small cap firms for two sub-periods of post and pre option listing. Results are shown in Table 2.

Table 2 shows that for the sample of 88 large cap firms, average variance has increased significantly subsequent to the stock option listing. For the samples for mid cap and small cap firms, post option listing variance has decreased, however the change is not statistically significant. For the overall sample of 166 firms, variance has increased after the listing of stock options. However, change in variance is not significant. Findings of significant change in variance for large cap firms contrasts with the previous studies of Rao, Tripathi, and Dukes [22], Bansal, Pruitt, and Wei [23], Skinner [24], and Conrad [25]. All of these studies reported a significant decline in return variance subsequent to the option listing. However, results of present study support the findings of Long, Schinski, and Officer [15], who reported that the effect of option listing may not be uniform across firms. Specifically, their results show that variance increases for the larger firms and decreases for the smaller firms, although these changes are not significant. Inference can be drawn from the above results that for large cap firms, where analyst coverage and trading volume are relatively high in comparison to mid-cap and small-cap firms, underlying stocks are displaying higher volatility subsequent to the option listing, and there is little gain from option listing. On the contrary, it shows that medium and smaller firms may have more to gain from option listing in terms of reduced volatility, as it moderates information asymmetry for these firms. A subsequent drop in the variance for mid cap and

Table 2. T-Test for two sample post and pre option listing daily variance assuming unequal means.

\begin{tabular}{cccccc}
\hline Categories & Total Firms & $\begin{array}{c}\text { Mean of Post } \\
\text { Option Listing } \\
\text { Variance (in } \\
\text { percentage) }\end{array}$ & $\begin{array}{c}\text { Mean of Pre } \\
\text { Option Listing } \\
\text { Variance (in } \\
\text { percentage) }\end{array}$ & $\begin{array}{c}\text { Change in Variance } \\
\text { (in percentage) }\end{array}$ & T-Statistic \\
\hline All Firms & 166 & 3.19 & 2.85 & 0.34 & 1.007 \\
Large Cap & 88 & 3.51 & 2.41 & 1.10 & $2.082^{* *}$ \\
Mid Cap & 55 & 2.62 & 3.20 & -0.58 & -1.40 \\
Small Cap & 23 & 3.29 & 3.67 & -0.38 & -0.443 \\
\hline
\end{tabular}

${ }^{*}$ Significant at $5 \%$ Level. 
small cap firms' underlying stocks can be explained as reduced information asymmetry for these firms. Generally mid cap and small cap firms have lower trading frequency and volume, and listing of stock options channelize informed trading in these stocks, resulting into lower drifts in stock prices on arrival of new information, and thus reduced variance.

GARCH Models are essentially filtering process that make use of the information in the entire estimation period to produce volatility estimates at one particular point in time. Since the GARCH techniques explicitly model the volatility process over time and enable to explore the link between information arrival in the market and its impact on market volatility, study also calculates average long run variance $\mathrm{V}_{\mathrm{L}}$ using $\mathrm{GARCH}(1,1)$ model for all the 166 stock returns for pre and post option listing periods. In practice, it is observed that variance rates tend to be pulled back to a long run average level. Therefore, GARCH $(1,1)$ model is preferred over the EWMA models, because former incorporates mean reversion process.

Table 3 presents the results of hypotheses test for change in long run variance $\left(\mathrm{V}_{\mathrm{L}}\right)$ using data of individual firms classified under large cap, mid cap, and small cap categories. For 129 out of 166 firms, null hypothesis cannot be rejected at 5\% level, while it is rejected for only 37 firms. Therefore, only 29.80 percent of the firms show significant change in long-run-variance $\mathrm{V}_{\mathrm{L}}$ using $\operatorname{GARCH}(1,1)$ model post option listing. This result is strikingly lower than the results for the measure of total risk, variance at 62.65 percent. Another important outcome is that, not a single small cap firm shows significant change in the long-run variance, while only 12.96 percent of the medium cap, and 33.78 percent of the large cap firms record significant change in average long-run variance. Overall, it can be inferred that option listing does not impact stock volatility using the long-run variance of GARCH $(1,1)$ model.

To know the overall effect of option listing on the firms' average long-run variance $\left(\mathrm{V}_{\mathrm{L}}\right)$ using GARCH $(1,1)$ model, a two sample t-test is conducted using $\mathrm{V}_{\mathrm{L}}$ data of 88 large cap, 55 mid cap, and 23 small cap firms for two sub-periods of post and pre option listing. Results are shown in Table 4. Highest average volatility is recorded for mid cap stocks in pre option listing period, followed by

Table 3. Results of hypotheses test for change in Long-Run-Variance $\left(\mathrm{V}_{\mathrm{L}}\right.$ using GARCH $(1,1)$ model on sample of large cap, mid cap, and small cap firms.

\begin{tabular}{|c|c|c|c|c|}
\hline Categories & $\begin{array}{c}\text { Null Hypothesis } \\
\text { Accepted (A) } \\
\sigma_{\text {Before }}^{2} / \sigma_{\text {After }}^{2}<\mathrm{F} \\
\text { Critical }\end{array}$ & $\begin{array}{c}\text { Null Hypothesis } \\
\text { Rejected (B) } \\
\sigma_{\text {Before }}^{2} / \sigma_{\text {After }}^{2}>\mathrm{F} \\
\text { Critical }\end{array}$ & Total (C) & $\begin{array}{l}\text { Significant Change in } \\
\text { Variance (in percent) } \\
(\mathrm{B}) /(\mathrm{C})\end{array}$ \\
\hline Large Cap & 58 & 30 & 88 & $33.78 \%$ \\
\hline Mid Cap & 48 & 7 & 55 & $12.96 \%$ \\
\hline Small Cap & 23 & 0 & 23 & $0.00 \%$ \\
\hline Total & 129 & 37 & 166 & $29.80 \%$ \\
\hline
\end{tabular}


Table 4. T-Test for two sample post and pre option listing daily value of Long-Run-Variance, $\left(\mathrm{V}_{\mathrm{L}}\right)$ using $\mathrm{GARCH}(1,1)$ model.

\begin{tabular}{cccccc}
\hline Categories & $\begin{array}{c}\text { Total } \\
\text { Firms }\end{array}$ & $\begin{array}{c}\text { Mean of Post Option } \\
\text { Listing Long-Run } \\
\text { Variance (in } \\
\text { percentage) }\end{array}$ & $\begin{array}{c}\text { Mean of Pre } \\
\text { Option Listing } \\
\text { Long-Run Variance } \\
\text { (in percentage) }\end{array}$ & $\begin{array}{c}\text { Change in } \\
\text { Variance (in } \\
\text { percentage) }\end{array}$ & T-Statistic \\
All Firms & 166 & 2.1791 & 2.1843 & -0.0052 & -0.0321 \\
Large Cap & 88 & 2.4830 & 2.4368 & 0.0463 & 0.1782 \\
Mid Cap & 55 & 2.4633 & 2.5377 & -0.0744 & -0.4521 \\
Small Cap & 23 & 0.4134 & 0.4210 & -0.0076 & -0.4351 \\
\hline
\end{tabular}

large cap, and lowest for small cap stocks. Whereas, for the post option listing period, highest volatility is recorded for the large cap sample, followed by mid cap and small cap firms. This is because after the option listing $\mathrm{V}_{\mathrm{L}}$ has increased for the sample of large cap firms, while it has declined for the sample of mid-cap firms. Results indicate that average long-run variance has decreased marginally after the option listing for the sample small cap firms. Overall sample of 166 firms, also exhibits a marginal decline in VL, post stock option listing. However, post option listing changes in average long-run variance $V_{L}$ for the sample of large cap, mid cap, small cap firms including the sample of all firms are not statistically significant at 5 percent level. Also, $\mathrm{R}^{2}$ of the GARCH $(1,1)$ regression model for individual firms is extremely low under both the sample periods of pre and post option listing.

These results of decline in long run variance $\mathrm{V}_{\mathrm{L}}$, (though only indicative and not statistically significant) after option listing for the overall sample of 166 firms, 55 mid cap firms and 23 small cap firms are consistent with the results of previous studies of Rao, Tripathi, and Dukes [22], Bansal, Pruitt, and Wei [23], Skinner [24], and Conrad [25]. A comparison between the results of hypotheses tests for pre and post option listing variance (Table 2), and average long run variance $\left(\mathrm{V}_{\mathrm{L}}\right)$ using GARCH $(1,1)$ model reveal some interesting facts. For the small cap firms' sample, the value of daily variance is quite high, while the value of average long-run variance $\left(\mathrm{V}_{\mathrm{L}}\right)$ is lowest amongst all the samples. This shows that $\operatorname{GARCH}(1,1)$ model capture the return volatility better for the small cap firms, which are characterized as illiquid, and information inefficient stocks. As the small cap firms have less analyst coverage, there is an information accumulation holdup, and then there are sudden outburst of high volatility periods, which increase the variance for these firms. Results again indicate that small cap firms benefit the most from the option listing, followed by midcap firms, as the values of average long run variance of GARCH $(1,1)$ also depict a decline in the post option listing period.

\section{Conclusions and Recommendations}

Study finds that in India effect of option listing is not uniform across all the firms. Volatility of the optioned stocks increases significantly for the large cap 
firms using daily variance and increases insignificantly using average long-run variance (VL) of GARCH $(1,1)$ model. Whereas, volatility for the optioned stocks decreases for the mid cap and small cap firms. These results, though indicative and not statistically significant, confirms the complete market hypothesis. For the large cap firms where trading volume and analyst coverage are high, option listing motivates the informed traders to collect private information and take option trading route, which results into higher volatility for these stocks. For mid cap and small cap firms which are characterized by low trading volume and absence of analyst coverage, option listing completes the market, and as a result, volatility declines after the option listing. Availability of index options in India before the stock option listing is valid for large stocks only, as most of the small cap stocks and mid cap stocks are not part of the indices on which index options were available before the stock option listing. An apparent deficiency of this study is its focus on a single emerging market i.e., India. In order to better study the topic in future, an extensive study can be conducted using cross country data for emerging markets. Also, augmenting the study with the results of E-GARCH models along with the currently used $\operatorname{GARCH}(1,1)$ will help to discern changes in pre and post option listing volatility due to positive and negative shocks.

Results of the study have implications for regulators, investors, portfolio managers, and firm's management as well. As option listing motivates the traders to collect private information about the long term investments made by firms, this results into enhanced informed trading activity in the underlying stocks, which consequently results into reduced information asymmetry and enhance market efficiency. Therefore, market regulators can allow option listing to enhance market efficiency in small cap and mid cap segments. In a market where optioned stocks are available, investors can take clues from the trading patterns and premiums in the options' market to adjust their positions. Portfolio managers can also rebalance their asset allocation using information from the options market, also they can hedge their positions effectively on highly volatile segments of small cap and mid cap stocks using stock options. Management of the smaller firms can benefit from option listing on their stocks, as it reduces return volatility, and provides pricing for the employee stock options ESOPs.

\section{Acknowledgements}

The author is thankful to the editor and referees for their valuable inputs and feedback.

\section{References}

[1] Black, F. and Scholes, M. (1973) Pricing of Options and Corporate Liabilities. Journal of Political Economy, 81, 637-654. https://doi.org/10.1086/260062

[2] Mayhew, S., and Mihov, V. (2004) How Exchanges Do Selects Stocks for Option Listing? The Journal of Finance, 59, 447-471.

https://doi.org/10.1111/j.1540-6261.2004.00638.x 
[3] Detemple, J. (1990). Financial Innovation, Values and Volatilities when Markets Are Incomplete. The Geneva Papers on Risk and Insurance-Theory, 15, 47-53. https://doi.org/10.1007/BF01498459

[4] Detemple, J. and Jorion, P. (1990) Option Listing and Stock Returns: An Empirical Analysis. Journal of Banking and Finance, 14, 781-801. https://doi.org/10.1016/0378-4266(90)90076-E

[5] Liu, S. (2010) Equity Options and Underlying Stock's Behavior: Further Evidence from Japan. International Review of Finance, 10, 293-312. https://doi.org/10.1111/j.1468-2443.2010.01121.x

[6] Ross, S. (1976) Options and Efficiency. The Quarterly Journal of Economics, 90, 75-89. https://doi.org/10.2307/1886087

[7] Black, F. (1975) Fact and Fancy in the Use of Options. Financial Analysts Journal, 31, 36-72. https://doi.org/10.2469/faj.v31.n4.36

[8] Detemple, J. and Selden, L. (1991) A General Equilibrium Analysis of Option and Stock Market Interactions. International Economic Review, 32, 279-303. https://doi.org/10.2307/2526876

[9] Easley, D., O’Hara, M. and Srinivas, P. (1998) Option Volume and Stock Prices: Evidence on Where Informed Traders Trade. The Journal of Finance, 53, 431-465. https://doi.org/10.1111/0022-1082.194060

[10] Cao, H. (1999) The Effect of Derivative Assets on the Information Acquisition and Price Behavior in a Rational Expectations Equilibrium. Review of Financial Studies, 12, 131-163. https://doi.org/10.1093/rfs/12.1.131

[11] Ni, S., Pan, J. and Potashman, A. (2008) Volatility Information Trading in the Option Market. The Journal of Finance, 63, 1059-1091. https://doi.org/10.1111/j.1540-6261.2008.01352.x

[12] Grossman, S. (1998) An Analysis of the Implications for Stock and Future Price Volatility of Program Trading and Dynamic Hedging Strategies. Journal of Business, 61, 275-298.

[13] Stein, J. (1987) Informational Externalities and Welfare-Reducing Speculation. Journal of Political Economy, 95, 1123-1145. https://doi.org/10.1086/261508

[14] Bhamra, H. and Uppal, R. (2006) The Effect of Introducing a Non-Redundant Derivative on the Volatility of Stock-Market Returns, Working Paper, University of British Columbia and London Business School, London.

[15] Long, D., Schinski, M. and Officer, D. (1994) The Impact of Option Listing on the Price Volatility and Trading Volume of Underlying OTC Markets. Journal of Economics and Finance, 18, 89-100. https://doi.org/10.1007/BF02920225

[16] Chen, D. and Chang, P. (2008) The Impact of Listing Stock Options on the Underlying Securities: The Case of Taiwan. Applied Financial Economics, 18, 1161-1172. https://doi.org/10.1080/09603100701537714

[17] Dong, Y., Fan, C. and Zhang, D. (2016) Does the Introduction of Stock Index Futures Destabilize the Spot Market? Some Cross-Country Evidence from Asia. The Chinese Economy, 49, 374-394. https://doi.org/10.1080/10971475.2016.1193393

[18] Vipul (2006) Impact of the Introduction of Derivatives on Underlying Volatility: Evidence from India. Applied Financial Economics, 16, 687-697. https://doi.org/10.1080/09603100600693816

[19] Chaturvedula, C. (2016) The Impact of Derivative Listing on the Indian Stock Market. The IUP Journal of Applied Economics, 15, 77-87.

[20] Bollerslev, T. (1986) Generalized Autoregressive Conditional Heteroscedasticity. 
Journal of Econometrics, 31, 307-327.

[21] Andersen, T. and Bollerslev, T. (1998) Answering the Sceptics: Yes, Standard Volatility Models Do Provide Accurate Forecasts. International Economic Review, 39, 885-905.

[22] Rao, R., Tripathi, N. and Dukes, W. (1991) Dealer Bid-Ask Spread and Options Trading on over the Counter Stocks. Journal of Financial Research, 14, 317-325. https://doi.org/10.1111/j.1475-6803.1991.tb00669.x

[23] Bansal, V., Pruitt, S. and Wei, K. (1989) An Empirical Reexamination of the Impact of CBOE Option Initiation on the Volatility and Trading Volume of the Underlying Equities. Financial Review, 24, 19-29. https://doi.org/10.1111/j.1540-6288.1989.tb00328.x

[24] Skinner, D. (1989) Options Markets and Stock Return Volatility. Journal of Financial Economics, 23, 61-78. https://doi.org/10.1016/0304-405X(89)90005-6

[25] Conrad, J. (1989) The Price Effect of Option Introduction. The Journal of Finance, 44, 487-498. 